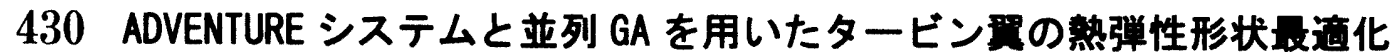

\section{Thermo-elastic Design Optimization of Turbine Blade Using ADVENTURE System with Parallel GAs}

\author{
○正 吉村忍（東大院・環境学） ブライアン・デニス（東大・計算科学技術連搭研究センター）
}

Shinobu YOSHIMURA, University of Tokyo, 7-3-1 Hongo, Bunkyo, Tokyo 113-8656

Brian Dennis , University of Tokyo

Key Words : Parallel CAE, Optimization, Genetic Algorithms, ADVENTURE, PC Cluster

\section{1. はじめに}

高速計算機 (HPC) 環境として、PC を多数ネットワーク接 続した PC クラスターが脚光を浴びている。その理由とし て、Linux やMPI などの良質でフリーのソフトウエア環境 が整ってきたこと、価格性能比が高いこと、初心者でも 比較的容易に高性能の並列処理環境を構筑できること、 比較的大規模なメモリ一空間・ディスク空間を実現でき ること、欲すれば 1 ユーザーが 24 時間占有できること、 などが挙げられる。また、昨今の超並列計算機 MPPs の多 くが汎用マイクロプロセッサを利用しており、PC クラス ターとの垣根は低くなりつつある。一方、アプリケーシ ヨンに着目すると、従来、PCクラスターやMPPs 環境で自

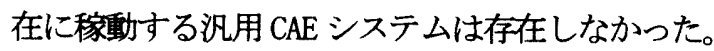

著者らは、日本学術振興会未来開拓学術研究推進事業 「計算科学」分野の ADVENTURE プロジェクトにおいて、 任意形状の実用力学問題を、 1 千万〜 1 億自由度級モデ ルを用いて解析や最適化計算ができる並列 CAE システム AVDENTURE を開発し、Ver. 1 を 2002 年 3 月にプロジェク トホームページから無料公開した ${ }^{(1-3)}$ 。

本論文では、ADVENTURE システムの実用性能を検証する 目的で実施したタービン翼の熱弾性最適設計について報 告する。

\section{ADVENTURE システムの特徽}

ADVENTURE システムでは、1千万から 1 億自由度級モデ ルを自由自在に扱えることと同時に、システムの開発・ 保守を容易にするために、背景知識や理論・アルゴリズ ム、プログラミングスタイルの異なる多数のプレ処理モ ジュール、メイン処理モジュール、ポスト処理モジュー ル、最適化モジュールを独立なモジュールとして構築し ている。各モジュールには領城分割型データ構造を基碳 とする並列アルゴリズムが実装されており、それぞれ単 独コードとして並列環境で稼動する。同時に各モジュー ルのデータ入出力は、並列分散環境での大規模解析を前 提とする標準的な I/0 (ADVENTURE_I0) ${ }^{(4)}$ によって統一さ れており、モジュール間の連搭を図りながら各種連成解 析や最適化解析を行い易いように設計されている。

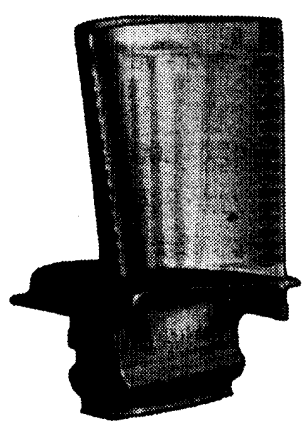

Fig. 1 Typical Turbine Blade

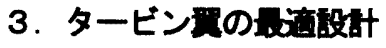

タービン翼は、Fig. 1 に示すように複雑な形状をしてお り、設計においては、空力特性、除熱特性、強度特性等 を同時に考虑することが求められる。しかし、3 次元モデ ルを用いた流体 - 熱 - 構造連成解析自体が極めて難しく、 さらに、形状を最適化することは、人工物設計問題の中 でも最も困難な問題の 1 つである。

先述したように、ADVENTURE システムでは、個別力学現 象を大規模モデルを用いて解析することはもちろんのこ と、最適化解析や弱連成解析を並列環境上で自在に行う ための基本的なメカニズムを寒現している( ${ }^{(5)}$ 。その実証 の第一段階として、本来は流体解析から定まるべき温度 境界条件を Fig. 2 に示すように固定し、内部冷却流路の 形状を設計変数とする熱弾性形状最適化問題に適用した。

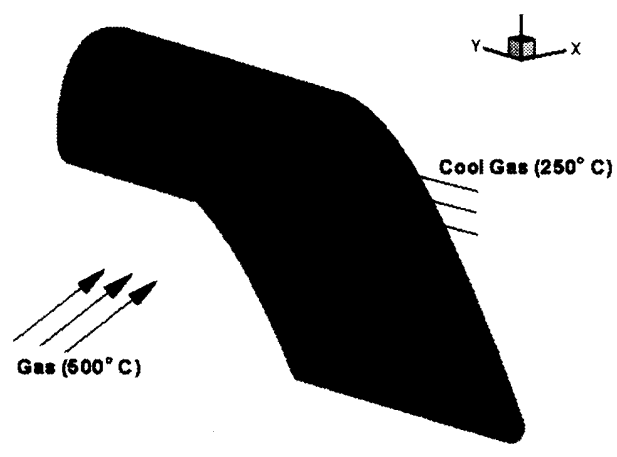

Fig. 2 Thermal Boundary Conditions

〔No.02-2〕日本機械学会第 15 回計算力学講演会講演論文集〔2002-11.2 4 ・鹿児島市〕 


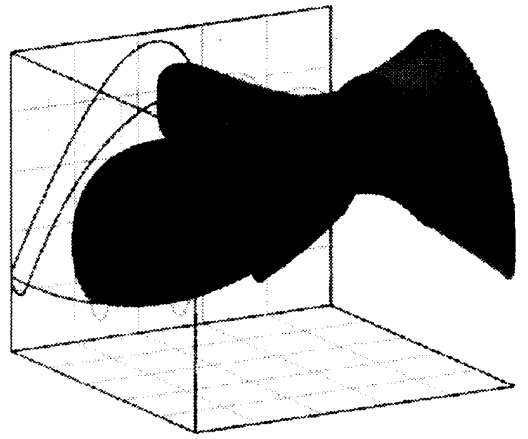

Fig. 3 Internal Passage in Turbine Blade

具体的には次の最適化問題を解いた。 目的関数:Fig. 3 に示すような内部冷却流路を有するブレ 一ドの重量を最小化する

制約条件 : 全域の発生温度が $500^{\circ} \mathrm{C}$ 以下 全域の発生応力が 740MPa 以下

設計変数 : 内部泠却流路の形状 (ベジェ・スプラインパ ッチ) の制御パラメータ

ADVENTURE システムの主要モジュール (ADV_Metis:領域 分割、ADV_Thermal: 熱解析、ADV_Solid:熱応力解析）は 並列化されており、一方、RGA (Real Coded GA) は容易に 並列化できるので、本研究では 2 段階の並列化を採用し た。その結果、並列計算機のプロセッサ資源を問題に応 じて効率的に利用することができる。並列 RGA では、人 ロサイズ 24、プロセッサ数 48 個、設計変数 40、一様交 さ、突然変異率は 5\%、制約はペナルティー法で処理、と した。各熱弾性解析には 2 プロセッサ(PenIII，500MHz) を利用し、FEM メッシュの平均サイズは 10 万自由度 (Fig. 4 参照)で、1 ケース当たり計算時間 10 分であった。

\section{4. 設結果}

Fig. 5 に世代進行に伴う重量変化の履歷を示す。 30 世 代で重量が 33\%程度削减された。Fig. 6 には、第 1 世代と 第 30 世代の解の表面温度分布を示す。流路形状最適化に よって温度条件も緩和されていることがわかる。なお、 今回の問題では、遠心力を考慮しなかったために、流路 が拡大し壁が薄くなることによって、軽量化が図られた が、遠心力を考虑することにより、最適解探索の難易度 は上がると予想される。

\section{5. おわりに}

ADVENTURE システムと並列 RGA を組み合わせるこ とにより、タービン頨の熱弾性形状最適化という実 用レベルの複雑な問題を PC クラスター環境で解け ることを示した。今後は、遠心力の考虑や流体力学 との連成など、解析モデルの高精度化を図っていく 予定である。

讨辞 本研究は、学振未来開拓「計算科学」分野の ADVENTURE プロジェクトの成果の一部である。

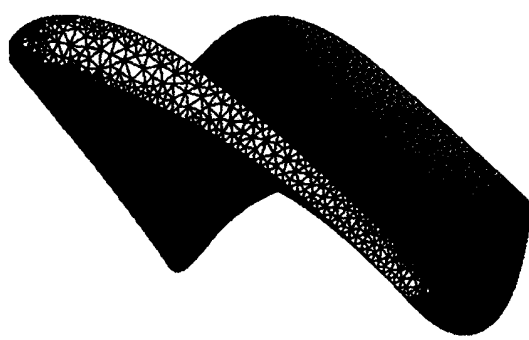

Fig. 4 An Typical Mesh

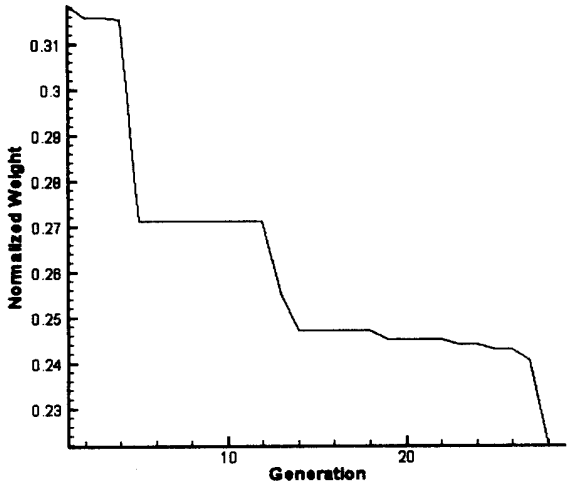

Fig. 5 Convergence of $\mathrm{GA}$-based Optimization

\section{考支文献}

(1) http://adventure. q. t. u-tokyo. ac. jp

(2) S. Yoshimura et al., Advanced General-purpose Computational Mechanics System for Large Scale Analysis and design, Journal of Computational and Applied Mathematics, in Print

（3）吉村、計算科学とバーチャル実証試験 : 学振末来開拓 ADVENTURE プロジェクトが提示する近未来、原誌、43-12, (2001) 1185-1190

（4）宮村、吉村ほか、大規模並列計算力学システムにおけ る入出カデータの標準化、日本計算工学会論文集, 2 (2000) 219-226

(5) Y. Nakabayashi, S. Yoshimura, G. Yagawa, FluidStructure Weak Coupled Analysis in a Parallel and Distributed Computer Environment, Computer Method in Applied Mechanics and Engineering, Accepted.

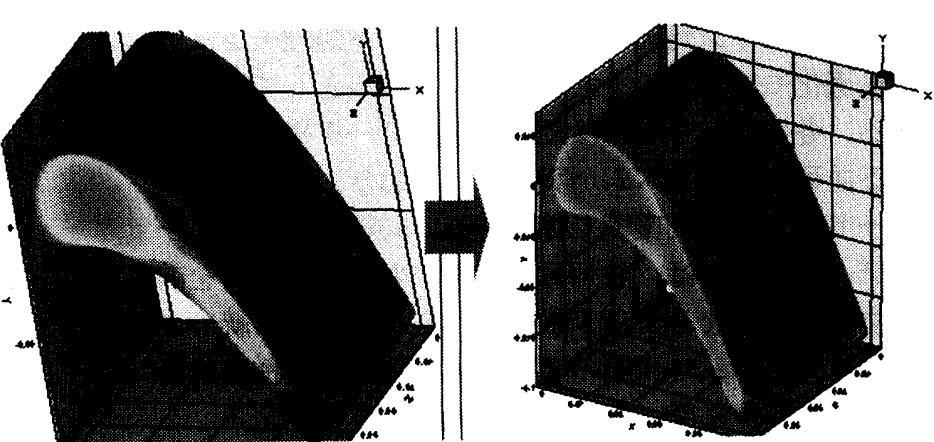

Fig. 6 Surface Temperature at 1st and 30th Generation Max Temperature Reduces from $496^{\circ} \mathrm{C}$ to $478^{\circ} \mathrm{C}$ 